\title{
PEMBUATAN DODOL JELLY DENGAN PENAMBAHAN AGAR STRIP (Gracilaria sp.) DI KABUPATEN KARAWANG
}

\author{
PRODUCTION OF JELLY DODOL WITH THE ADDITION OF AGAR STRIP \\ (Gracilaria sp.) IN KARAWANG REGENCY
}

\section{Anasri Tanjung, Rahmad S. H. Saputra*, Sukma Budi Prasetyawati, Catur Pramono Adi}

\author{
Politeknik Kelautan dan Perikanan Karawang, Jalan Lingkar Tanjungpura, Karangpawitan, Kecamatan \\ Karawang Barat, Kabupaten Karawang, Jawa Barat 41315
}

Teregistrasi I tanggal: 17 April 2020; Diterima setelah perbaikan tanggal: 09 Juli 2020; Disetujui terbit tanggal: 13 Juli 2020

\begin{abstract}
ABSTRAK
Kabupaten Karawang merupakan salah satu daerah penghasil rumput laut jenis Gracilaria sp. Untuk meningkatkan nilai jualnya, rumput laut Gracilaria sp. dapat diolah menjadi agar strip. Agar strip Gracilaria sp. kemudian digunakan sebagai bahan baku pembuatan dodol jelly. Menurut SNI 01-2986- 1992, dodol merupakan sejenis makanan yang terbuat dari tepung beras ketan, santan kelapa, dan gula dengan atau tanpa penambahan bahan lainnya yang diizinkan. Namun dalam perkembangannya, dodol dapat dibuat dari bermacam-macam bahan makanan, misalnya dodol buah Garut atau dodol jelly rumput laut khas Lombok. Tujuan penelitian ini untuk memformulasikan produk dodol yang diolah dari karaginan dan agar strip Gracilaria sp. serta menguji kualitas sensori dodol tersebut. Penambahan agar strip Gracilaria sp. mempengaruhi mutu sensori produk dodol jelly pada parameter tekstur. Formulasi bahan dodol jelly meliputi: agar Gracilaria sp, karaginan, gelatin, sirup glukosa, sukrosa, pewarna makanan dan air. Dodol jelly yang dihasilkan memiliki kenampakan jernih dan tekstur kenyal. Nilai tertinggi 4.15 untuk rata-rata kesukaan panelis terhadap tekstur yakni dodol jelly tanpa penambahan agar strip. Untuk warna rata-rata panelis menyukai produk dengan penambahan agar strip 5 gram. Untuk penilaian terhadap aroma semua panelis menyukai aroma dodol dengan atau tanpa penambahan agar strip.
\end{abstract}

Kata kunci: agar strip, dodol jelly, Gracilaria sp.

\begin{abstract}
Karawang Regency is one of the seaweed producing areas of Gracilaria sp. To increase the sale value, Gracilaria sp. seaweed can be processed into agar strips. The agar strip of Gracilaria sp. is then used as a raw material for making jelly dodol. According to SNI 01-2986-1992, dodol is a type of food made from glutinous rice flour, coconut milk, and sugar with or without the addition of other permitted ingredients. But in its development, dodol can be made from a variety of food ingredients, for example, dodol Garut or jelly dodol from Lombok. The purpose of this study was to formulate dodol products which were processed from carrageenan and G. verrucosa strips and to test the sensory quality of dodol. The addition of Gracilaria sp. agar strips affected the sensory quality of jelly dodol products on texture parameter. Formulation of jelly dodol includes: Gracilaria sp. agar, carrageenan, gelatin, glucose syrup, sucrose, food coloring, and
\end{abstract}

\footnotetext{
Korespondensi penulis:

*Email: rahmad.surya@poltekkpkarawang.ac.id
}

DOI: http://dx.doi.org/10.15578/plgc.v1i3.8913 
water. The result of jelly dodol has a clear appearance and chewy texture. The texture of jelly dodol without the addition of agar strips has the highest average value preference (4.15) from the panelists. The color of products with the addition of 5 gram of agar strips has the most preference value by the panelists. For the assessment of the aroma, the panelists preferred the aroma of dodol with or without the addition of agar strips.

Keywords: agar strips, jelly dodol, Gracilaria sp.

\section{PENDAHULUAN}

Kabupaten Karawang merupakan salah satu wilayah pesisir di Indonesia yang memiliki berbagai sumber daya hayati kelautan. Salah satu sumberdaya kelautan yang melimpah di Karawang adalah rumput laut jenis Gracilaria verrucosa, yang produksinya pada tahun 2017 mencapai 419,28 ton (Badan Pusat Statistik, 2018; Waluyo et al., 2019). Namun rumput laut yang dihasilkan umumnya dijual dalam bentuk bahan mentah berupa rumput laut kering dengan harga yang rendah (Purwanto et al., 2013).

Untuk meningkatkan nilai jualnya, rumput laut G. verrucosa dapat diolah menjadi berbagai produk nilai tambah (Purwanto et al., 2013). Hal ini didorong oleh kandungan nutrisi rumput laut yang beraneka ragam, seperti metabolit primer dan metabolit sekunder. Kandungan metabolit primer dalam rumput laut meliputi protein, asam lemak, dan polisakarida seperti agar, karaginan, dan alginat. Sedangkan kandungan metabolit sekunder dalam rumput laut meliputi senyawa-senyawa bioaktif seperti antioksidan (Almeida et al., 2011).

Balai Besar Pengujian Penerapan Hasil Perikanan Kementerian Kelautan dan Perikanan (BBP2HP-KKP) telah mengembangkan produk diversifikasi olahan G. verrucosa menjadi agar strip. Produk pangan lain yang menggunakan bahan baku rumput laut adalah dodol rumput laut. Dodol rumput laut merupakan makanan semi basah yang memerlukan pengolahan khusus agar dihasilkan bentuk akhir dodol yang sesuai dengan syarat-syarat makanan semi basah (Purwanto et al., 2013).

$$
\text { Menurut SNI 01-2986- } 1992
$$

(Dodol), dodol merupakan sejenis makanan yang terbuat dari tepung beras ketan, santan kelapa, dan gula dengan atau tanpa penambahan bahan lainnya yang diizinkan. Namun dalam perkembangannya, dodol dapat dibuat dari bermacam-macam bahan makanan, misalnya dodol buah Garut atau dodol jelly rumput laut khas Lombok. Dodol merupakan salah satu jenis makanan tradisional yang lama dikenal oleh kalangan masyarakat, yang berbahan dasar tepung ketan. Dodol memiliki tekstur plastis, padat dan mempunyai kadar air 10 - 40\% (Haliza, 2002).

Dodol rumput laut adalah makanan olahan modifikasi dodol yang dibuat dengan menambahkan rumput laut untuk meningkatkan nilai guna rumput laut. Dodol tergolong dalam pangan semi basah (intermediate moisture food) yang bertekstur kenyal, memiliki cita rasa manis sehingga dapat langsung dimakan.

Pengolahan dodol rumput laut dengan penambahan agar strip yang tergolong sederhana berpotensi untuk dialih teknologikan kepada masyarakat Kabupaten Karawang dengan mudah. Namun sebelum metode pengolahan dan produk dodol rumput laut dapat dialihteknologikan dan dipasarkan, tentunya kualitas produk dodol yang dihasilkan harus sesuai dengan standar produk yang berlaku, seperti SNI 7761:2013 (BSN, 2013) tentang dodol rumput laut. Sebab, kebanyakan dodol rumput laut yang dibuat di masyarakat memiliki kenampakan keruh dan kusam. 
Karakteristik fungsional dodol yang diinginkan berhubungan dengan sifat struktural produk pangan olahan yaitu tekstur. Rumput laut dapat digunakan sebagai bahan tambahan dalam produk. Rumput laut yang digunakan jenis Eucheuma cottoni, mampu menghasilkan karaginan untuk meningkatkan kekenyalan pada tekstur dodol (Lukito et al., 2017). Salah satu kandungannya yang berperan dalam pembentukan tekstur adalah karaginan. Kandungan nutrisi dodol rumput laut ditunjukkan pada Tabel 1 (Ayu et al., 2012).

\section{BAHAN DAN METODE Waktu dan Tempat}

Penelitian ini dilaksanakan di Unit Teaching Factory Pengolahan Politeknik KP Karawang pada Juni sampai Desember 2019.

\section{Bahan}

Bahan yang digunakan dalam penelitian ini adalah agar strip Gracilaria sp., karaginan, gelatin, sirup glukosa, sukrosa dan pewarna makanan, dan air.

\section{Formulasi bahan}

Formulasi bahan dodol jelly rumput laut menggunakan perbandingan agar strip Gracilaria sp dan ekstrak karaginan dilihat pada Tabel 2.

Formulasi dodol jelly mengacu pada resep dodol dan permen jelly yang dikembangkan oleh Balai Besar Pengujian
Tabel 1. Komposisi kimia dodol rumput laut Table 1. Chemical composition of seaweed dodol

\begin{tabular}{lc}
\hline Komposisi & Nilai $(\boldsymbol{\%})$ \\
\hline Kadar abu & 0,22 \\
Kadar air & 15,85 \\
Kadar protein & 1,56 \\
Kadar lemak & 0,95 \\
Kadar karbohidrat & 76,92 \\
Kadar serat kasar & 3,10 \\
Kadar iodium & 3,18 \\
\hline Sumber: Ayu et al. (2012)
\end{tabular}

Tujuan dari penelitian ini adalah memformulasikan (membuat komposisi) produk dodol yang diolah dari karaginan dan agar strip Gracilaria sp. serta menguji kualitas sensori dodol tersebut.

Penerapan Hasil Perikanan (BBP2HPKKP), dengan dilakukan modifikasi terhadap komposisi bahan yaitu penambahan agar strip Gracilaria sp. Umumnya agar memiliki karakteristik rigid, rapuh dan mudah dibentuk. Dibutuhkan kombinasi yang tepat dengan karaginan agar membentuk tekstur yang kenyal dan lentur menyerupai dodol secara umum. Setelah dilakukan percobaan pendahuluan untuk menentukan konsentrasi agar strip, maka didapatkan jumlah yang diinginkan yakni 3 gram dan 5 gram. Bila agar strip ditambahkan lebih dari 5 gram per $650 \mathrm{ml}$ air, tekstur dodol jelly yang terbentuk rapuh dan mudah patah.

\section{Alat}

Alat pengolahan dodol rumput laut antara lain panci stainless steel, baki/tray, spatula, dan blender, gelas ukur.

Tabel 2. Formulasi bahan

Table 2. Ingredient Formulation

\begin{tabular}{clccc}
\hline \multirow{2}{*}{ No } & \multicolumn{1}{c}{ Bahan } & \multicolumn{3}{c}{ Kode Sampel } \\
\cline { 3 - 5 } & & $\mathrm{A} 1$ & $\mathrm{~A} 2$ & $\mathrm{~A} 3$ \\
\hline 1 & Agar strip Gracilaria sp & $3 \mathrm{~g}$ & $5 \mathrm{~g}$ & $0 \mathrm{~g}$ \\
2 & Karaginan & $15 \mathrm{~g}$ & $15 \mathrm{~g}$ & $15 \mathrm{~g}$ \\
3 & Sirup glukosa & $50 \mathrm{~g}$ & $50 \mathrm{~g}$ & $30 \mathrm{~g}$ \\
4 & Sukrosa & $150 \mathrm{~g}$ & $150 \mathrm{~g}$ & $150 \mathrm{~g}$ \\
5 & Gelatin & $15 \mathrm{~g}$ & $15 \mathrm{~g}$ & $15 \mathrm{~g}$ \\
6 & Air & $650 \mathrm{ml}$ & $650 \mathrm{ml}$ & $650 \mathrm{ml}$ \\
7 & Pewarna makanan & & secukupnya & \\
\hline
\end{tabular}




\section{Uji sensori}

Uji sensori dilakukan melalui uji hedonik yaitu kesukaan dodol jelly. Panelis yang menguji merupakan panelis semi terlatih menggunakan uji ranking hedonik. Parameter yang digunakan antara lain tingkat kesukaan terhadap tekstur, warna, rasa, dan aroma. Panelis diminta mengurutkan sesuai dengan skala $1-5$ yang menunjukan tingkat kesukaan mulai dari sangat tidak suka sampai sangat suka (Tanjung et al., 2020). Jumlah panelis yang melakukan uji adalah 30 orang yang dilakukan di teaching factory Pengolahan Politeknik Kelautan dan Perikanan Karawang.

\section{Rancangan penelitian}

Rancangan penelitian ini menggunakan Rancangan Acak Lengkap dimana variabel yang digunakan adalah perbandingan jumlah agar strip Gracilaria sp. yang ditambahkan ke dalam adonan dodol. Sampel objek penelitian dibagi menjadi 3 (tiga) kelompok percobaan yaitu:

A1 : kelompok penambahan agar strip 3 gram

A2 : kelompok penambahan agar strip 5 gram

A3 : kelompok kontrol negatif (dodol tanpa penambahan agar strip)

\section{Analisis data}

Data hasil uji sensori diolah menggunakan metode statistik Analysis of Variance Test (ANOVA). Data yang didapat jika terdapat perbedaan nyata dilanjutkan dengan uji Beda Nyata Terkecil (BNT) taraf kepercayaan 95\% $(\alpha=0,05)$. Data uji sensori dianalisis secara deskriptif yang disajikan dalam bentuk tabel dan diagram batang. Hipotesis yang digunakan adalah:

$\mathrm{H}_{0}: \mu_{1}=\mu_{2}=\mu_{3}$, tidak terdapat perbedaan rata-rata kesukaan panelis terhadap parameter sensori (tekstur, warna, aroma, rasa).
$\mathrm{H}_{0}: \mu_{1} \neq \mu_{2} \neq \mu_{3}$, terdapat perbedaan ratarata kesukaan panelis terhadap parameter sensori (tekstur, warna, aroma, rasa).

Jika $\mathrm{F}_{\text {hitung }}>\mathrm{F}_{\text {tabel}}$, maka tolak $\mathrm{H}_{0}$; sebaliknya jika $F_{\text {hitung }} \leq F_{\text {tabel, }}$ maka terima $\mathrm{H}_{0}$.

\section{HASIL DAN BAHASAN HASIL}

Dodol rumput laut dibuat dengan cara memasak agar strip dalam air agar larut pada suhu sekitar $90^{\circ} \mathrm{C}$. Setelah agar strip larut, kemudian tambahkan esktrak karaginan yang dilarutkan dengan air dingin ke adonan agar strip. Adonan diaduk hingga homogen, lalu tambahkan sirup glukosa dan sukrosa. Sebelum ditambahkan, gelatin dilarutkan dengan air hangat agar mudah menyatu dengan adonan. Pada tahap akhir, aduk adonan hingga mengental.

Selanjutnya adonan dituang ke loyang untuk didinginkan. Proses pendinginan dilakukan pada suhu ruangan kurang lebih selama 1 jam. Adonan yang telah diturunkan suhunya kemudian dimasukkan ke dalam lemari pendingin. Tujuannya adalah untuk mempercepat pembentukan tekstur dodol yang cukup liat. Penyimpanan dalam lemari pendingin dilakukan selama 24 jam. Dodol yang sudah liat dipotong sesuai selera kemudian dikeringkan untuk menurunkan kadar airnya. Pengeringan dapat dilakukan dengan sinar matahari selama kurang lebih 2 hari atau menggunakan oven selama 2 hari dengan suhu $60^{\circ} \mathrm{C}$. Pada penelitian ini, pengeringan yang dilakukan menggunakan sinar matahari sebab sirkulasi udara yang baik dapat mempercepat proses penguapan air dari dodol jelly. Alur proses permbuatan dodol jelly dapat dilihat pada Gambar 1 .

Dodol jelly yang telah dikeringkan memiliki kenampakan bening, tekstur kenyal, serta tidak mudah patah jika dilipat. Penampakan masing-masing sampel dapat dilihat pada Gambar 2. 


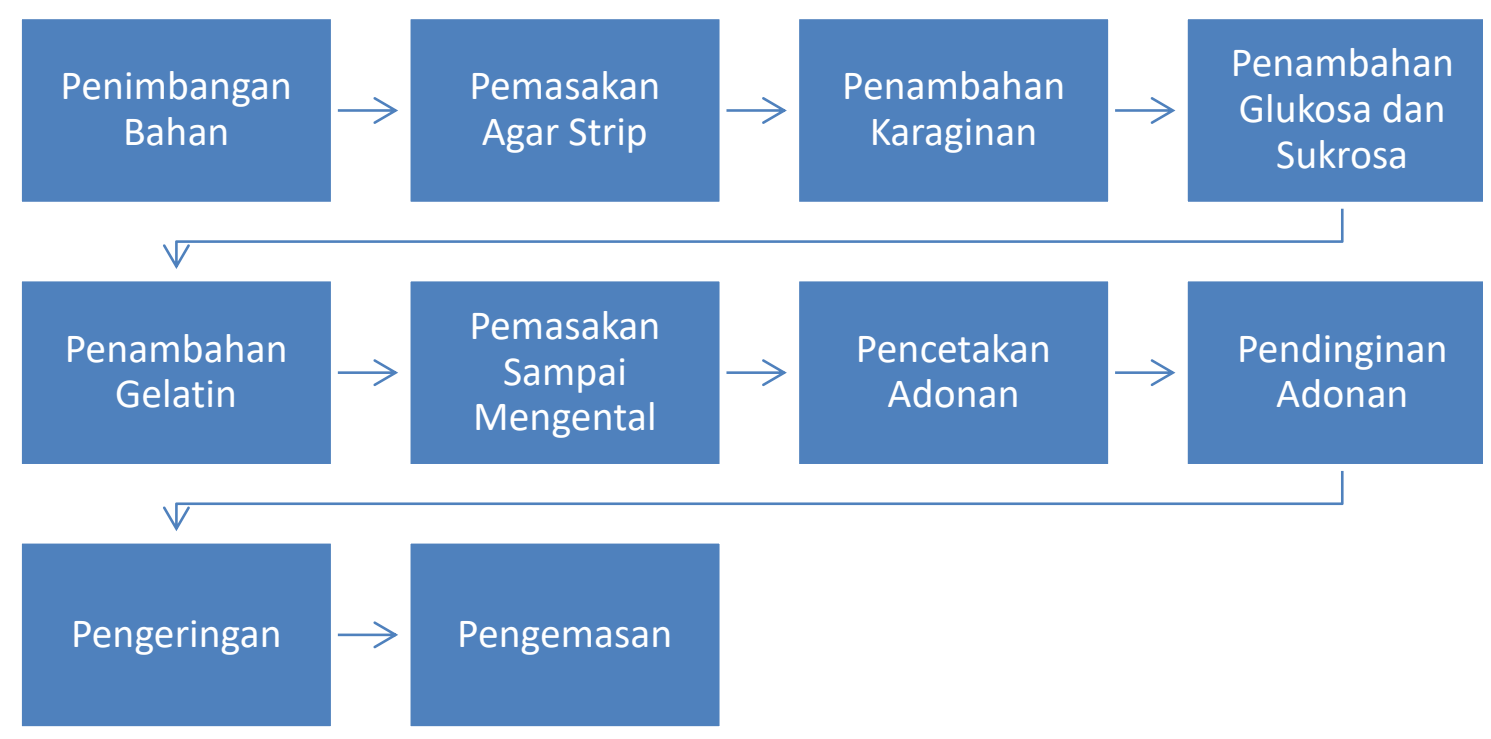

Gambar 1. Alur proses pembuatan dodol

Figure 1. The process flow of dodol making

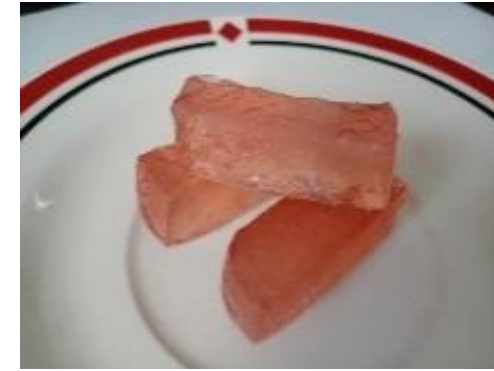

a. A1

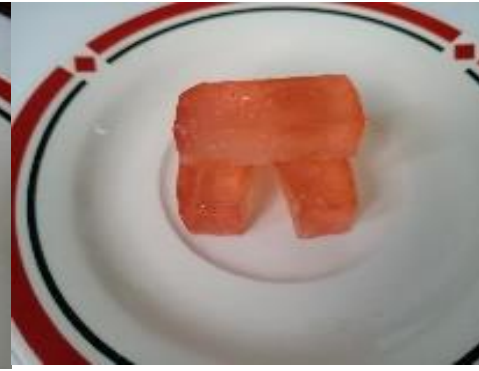

b. A2

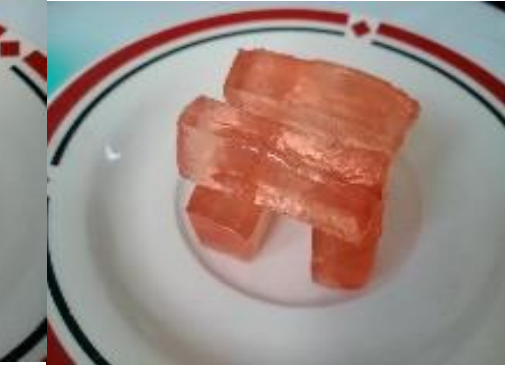

c. A3

Gambar 2. Sampel dodol rumput laut.

Figure 2. Three sample of dodol

\section{BAHASAN}

Uji sensori

Uji sensori dilakukan melalui uji hedonik yakni uji kesukaan dodol jelly dengan parameter tekstur, warna, aroma, dan rasa. Rata-rata hasil uji hedonik terhadap parameter tekstur dapat dilihat pada Gambar 3.

Dari diagram batang tersebut (Gambar 3) dapat disimpulkan, bahwa nilai tertinggi untuk rata-rata kesukaan panelis terhadap tekstur adalah sampel A3 yakni dodol jelly tanpa penambahan agar strip. Nilai 4,15 bermakna rata-rata panelis menyukai dodol jelly tanpa penambahan agar strip. Tekstur kenyal pada dodol jelly didapatkan dari karaginan dan gelatin.
Adapun produk A1 dan A2, rata-rata panelis memberikan penilaian netral, artinya dodol jelly dengan penambahan 3 gram dan 5 gram agar strip masih dapat diterima oleh panelis.

Hasil analisis ANOVA terhadap parameter tekstur menunjukkan bahwa nilai $F_{\text {hitung }}$ adalah 18,303 lebih besar dibandingkan $\mathrm{F}_{\text {tabel }}$ yakni 3,101; sehingga kesimpulannya adalah tolak $\mathrm{H}_{0}$. Penambahan agar strip pada dodol jelly memberikan pengaruh yang nyata kesukaan panelis terhadap tekstur. Pengujian dilanjutkan dengan uji Beda Nyata Terkecil (BNT) untuk menentukan apakah rata-rata perlakuan berbeda secara nyata atau tidak. Hasil uji BNT menunjukkan bahwa produk A1 


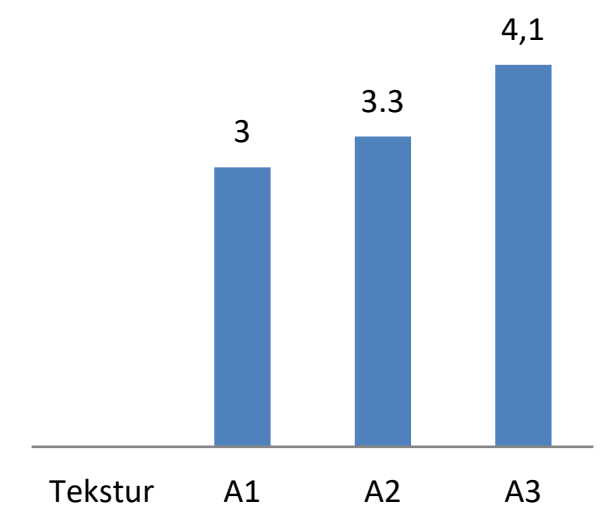

Gambar 3. Nilai preferensi tekstur dodol jelly rumput laut

Figure 3. Texture Hedonic Test Value

(penambahan agar strip 3 gram) dan produk A2 (penambahan agar strip 5 gram) berbeda nyata dengan produk A3 (tanpa penambahan agar strip). Artinya, penambahan agar strip memberikan pengaruh terhadap kesukaan panelis terhadap tekstur dodol jelly, dalam hal ini rata-rata panelis memilih produk A3 yang disukai. Sedangkan produk A1 tidak berbeda nyata dengan produk A2, artinya penambahan agar strip 3 gram maupun 5 gram tidak mempengaruhi kesukaan panelis. Komposisi utama dodol jelly adalah karaginan dan gelatin, dimana keduanya memberikan tekstur kenyal pada bahan. Adapun agar strip Gracilaria sp., sebagaimana agar pada umumnya bersifat rigid, rapuh dan mudah dibentuk (Sukamulyo, 1989). Tekstur dodol jelly menjadi lebih rapuh dengan adanya penambahan agar strip.

Parameter uji hedonik yang kedua adalah warna. Warna makanan mempengaruhi penerimaan konsumen terhadap suatu produk. Dalam industri pengolahan, banyak dijumpai makananmakanan yang menggunakan bahan tambahan pewarna untuk membuat produknya menjadi menarik. Bahan tambahan pewarna ini sangat dianjurkan untuk menggunakan sumber pewarna alami maupun pewarna sintetis khusus makanan. Pada pembuatan dodol jelly, pewarna yang digunakan adalah pewarna sintetis makanan berwana merah (bit). Hasil uji hedonik terhadap parameter warna dapat dilihat pada Gambar 4.

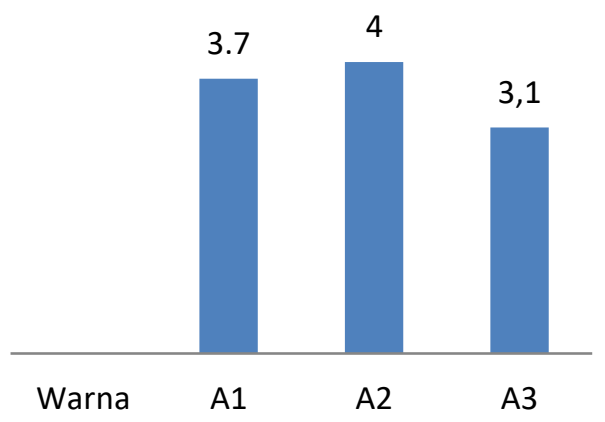

Gambar 4. Nilai preferensi warna dodol jelly rumput laut

Figure 4. Color Hedonic Test Value

Dari diagram batang (Gambar 4), dapat disimpulkan bahwa rata-rata panelis menyukai produk A1 dan A2 dengan nilai rata-rata tertinggi adalah produk A2 (penambahan agar strip 5 gram) yaitu 4 . Sedangkan untuk produk A3, rata-rata panelis memberikan penilaian 3,1 yang artinya netral.

Hasil analisis ANOVA terhadap parameter warna menunjukkan bahwa nilai $F_{\text {hitung }}$ adalah 10,155 lebih besar dibandingkan $F_{\text {tabel }}$ yakni 3,101; sehingga kesimpulannya adalah tolak $\mathrm{H}_{0}$. Penambahan agar strip pada dodol jelly memberikan pengaruh yang nyata pada tingkat kesukaan panelis terhadap warna. Akan tetapi hasil uji BNT menunjukkan bahwa produk A1, produk A2 maupun A3 tidak berbeda nyata. Pada penelitian ini, pewarna makanan yang ditambahkan pada tiap perlakuan memiliki konsentrasi yang sama, sehingga tidak ditemukan perbedaan pengaruhnya.

Parameter ketiga dari uji hedonik adalah aroma. Penerimaan konsumen terhadap produk makanan, salah satunya dipengaruhi oleh aroma. Rata-rata hasil uji hedonik aroma dodol jelly dapat dilihat pada Gambar 5.

Dari diagram pada Gambar 5, dapat disimpulkan bahwa rata-rata panelis 


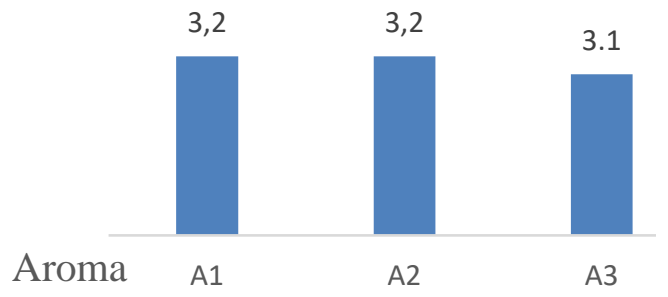

Gambar 5 Nilai preferensi aroma dodol jelly rumput laut

Figure 5. Aroma Hedonic Test Value

memberikan penilaian sama pada produk A1, produk A2 serta produk A3 yaitu 3 terhadap parameter aroma yang artinya biasa.

Hasil analisis ANOVA terhadap parameter aroma menunjukkan bahwa nilai $F_{\text {hitung }}$ adalah 0,025 lebih kecil dibandingkan $\mathrm{F}_{\text {tabel }}$ yakni 3,101; sehingga kesimpulannya adalah terima $\mathrm{H}_{0}$ yang bermakna bahwa tidak terdapat perbedaan rata-rata kesukaan panelis terhadap parameter aroma. Aroma dari dodol jelly berasal dari essence strawberry yang sekaligus berfungsi sebagai pewarna. Sedangkan konsentrasi essence strawberry yang ditambahkan pada produk A1, produk A2 dan produk A3 sama.

Parameter keempat dari uji hedonik adalah rasa. Penilaian sensori rasa seringkali menjadi penentu apakah sebuah produk pangan akan diterima atau tidak oleh konsumen. Rata-rata hasil uji hedonik rasa dodol jelly dapat dilihat pada Gambar 6.

Dari diagram batang (Gambar 6), dapat disimpulkan bahwa rata-rata panelis memberikan penilaian sama (dengan pembulatan) pada produk A1, produk A2 serta produk A3 yaitu 4 terhadap parameter rasa yang artinya suka.

Hasil analisis ANOVA terhadap parameter aroma menunjukkan bahwa nilai $F_{\text {hitung }}$ adalah 4,23 lebih besar dibandingkan $\mathrm{F}_{\text {tabel }}$ yakni 3,101; sehingga kesimpulannya adalah tolak $\mathrm{H}_{0}$ yang bermakna bahwa terdapat perbedaan rata- rata kesukaan panelis terhadap parameter rasa. Uji dilanjutkan dengan BNT dengan hasil bahwa produk A1 (penambahan agar strip 3 gram) dan produk A2 (penambahan agar strip 5 gram) berbeda nyata dengan produk A3 (tanpa penambahan agar strip). Hal ini menunjukkan penambahan agar strip memberikan pengaruh terhadap kesukaan panelis terhadap rasa dodol jelly, dalam hal ini rata-rata panelis memilih produk A3 yang disukai. Sedangkan produk A1 tidak berbeda nyata dengan produk A2, artinya penambahan agar strip 3 gram maupun 5 gram tidak mempengaruhi kesukaan panelis. Rasa dodol dihasilkan oleh penambahan sirup glukosa dan sukrosa. Sirup glukosa yang ditambahkan pada produk A3 sebanyak 30 gram, lebih sedikit dibandingkan yang ditambahkan pada produk A1 dan A2 yakni 50 gram. Hasil ini menunjukkan bahwa panelis lebih menyukai rasa dodol jelly yang tidak terlalu manis.

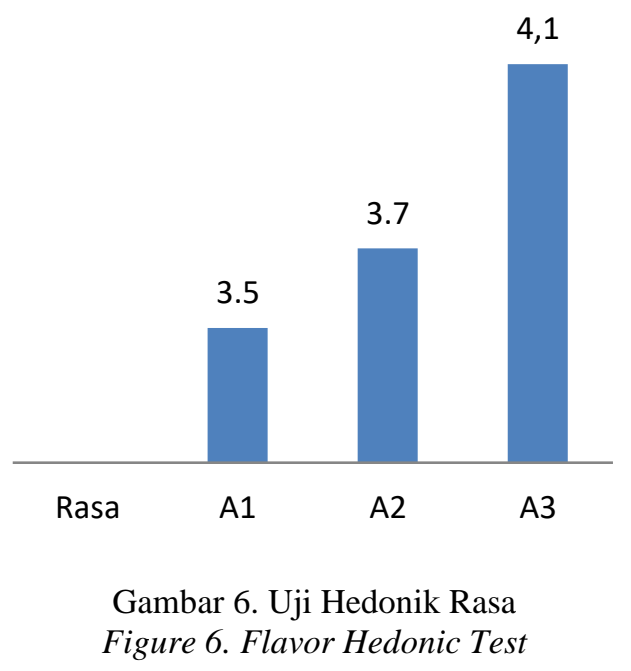

\section{SIMPULAN}

Berdasarkan pembahasan di atas maka dihasilkan kesimpulan sebagai berikut:

1. Setelah dilakukan berbagai pengujian hedonik terhadap tekstur, warna, aroma dan rasa terhadap formulasi dodol jelly dengan penambahan agar strip Gracilaria sp. yang telah di buat dapat diterima oleh panelis; 
2. Uji sensori menggunakan uji hedonik pada 30 panelis memberikan hasil bahwa penambahan agar strip Gracilaria sp. tidak memberikan pengaruh terhadap tekstur dodol;

3. Uji sensori menggunakan uji hedonik pada 30 panelis memberikan hasil bahwa penambahan agar strip Gracilaria sp. 5 gram panelis memberikan penilaian tertinggi terhadap warna;

4. Uji sensori menggunakan uji hedonik pada 30 panelis memberikan hasil bahwa dengan atau tanpa penambahan agar strip semua panelis menyukai aroma dodol.

\section{DAFTAR PUSTAKA}

Ayu, S. D., Nadimin, Rauf, S. (2012). Pengaruh konsentrasi bahan dasar pada pembuatan dodol multi gizi terhadap kandungan zat gizi. Media Gizi Pangan, 13(1), 25-29.

[BBPHP] Balai Besar Pengujian Hasil Perikanan. (2019). Agar Strip, Inovasi Pangan Sehat dari Rumput Laut. Balai Besar Pengujian Hasil Perikanan, Jakarta. https://kkp.go.id/djpdspkp/artikel/1 4141-agar-strip-inovasi-pangansehat-dari-rumput-laut. 16 April 2020 (14:30).

[BPS] Badan Pusat Statistik. (2018). Kabupaten Karawang Dalam Angka. Karawang: BPS Kabupaten Karawang.

[BSN] Badan Standardisasi Nasional. (1992). SNI 01-2986- 1992 Dodol. Jakarta: Badan Standardisasi Nasional. . (2013). SNI 7761:2013

Dodol Rumput Laut. Jakarta: Badan Standardisasi Nasional.
Almeida, D., Cynthia, L. F. De., Falcão, D.S., Lima, D. M., Gedson, R., Montenegro, D. A., Narlize, S. L., Filho, D. A., Rodrigues, F. P. L. C., \& Maria, D. (2011). Bioactivities from marine algae of the Genus Gracilaria. International Journal of Molecular Sciences, 12 (7), 45504573.

Haliza. (2002). Rancangan proses pembuatan dodol kweni (Mangifera adorata Griff). Jakarta: Penebar Swadaya.

Lukito, M. S., Giyarto, G., \& Jayus, J. (2017). Sifat fisik, kimia dan organoleptik dodol hasil variasi rasio tomat dan tepung rumput laut. Jurnal Agroteknologi, 11(01), 82-95.

Purwanto, R. O., Dwiargo, B., \& Hermanto, M. B. (2013). Pengaruh komposisi sirup glukosa dan variasi suhu pengeringan terhadap sifat fisika-kimia dan inderawi dodol rumput laut (Eucheuma spinosium). Jurnal Bioproses Komoditas Tropis 1(1), 1-12.

Sukamulyo, S. (1989). Mempelajari cara ekstraksi dengan praperlakuan asam dalam pembuatan agar dari Gelidium sp. Skripsi. Fakultas Teknologi Pertanian IPB. Bogor.

Tanjung, A., Prasetyati, S. B., Wardani, A. K., \& Saputra, R. S. H. (2020). Pengaruh penambahan arang aktif terhadap mutu sabun mandi cair rumput laut (Gracilaria sp.). PELAGICUS, 1(1), 31-38.

Waluyo, Permadi, A., Fanni, N. A., \& Soedrijanto, A. (2019). Analisis kualitas rumput laut Gracilaria Verrucosa di Tambak Kabupaten Karawang, Jawa Barat. Grouper, 10 (1), 32-41. 